\title{
In Asia, Does Airline Service Quality Matter to Investors?
}

\author{
Samuel D. Barrows ${ }^{1,2}$ \\ ${ }^{1}$ Senior Lecturer at STEM Business School, Turan University, Kazakhstan \\ 2 Doctorate of Business Administration Candidate, Toulouse Business School, France \\ Correspondence: Samuel D. Barrows. E-mail: sam_barrows@yahoo.com
}

Received: January 5, 2018

doi:10.5539/ass.v14n4p8

\begin{abstract}
The purpose of this study is to evaluate whether premium services airlines in Asia offer better returns to investors as compared to normal services airlines. To accomplish this, portfolios are created for each airline group and compared against benchmarks in monthly assessments over a sixty two month period ending in October 2017. The benchmarks include the global market and the oil market. The global market offers a comparison to a baseline expectation while the oil market represents a major cost component for the airline industry. The findings point to the premium services airlines as being the superior performing group in relation to the normal services airlines as judged in six cases using various configurations of the benchmarks. These results are further confirmation that in some industry segments, service quality matters. Included is literature pertaining to service quality, loyalty, and profitability. Each of these topics is expanded to show the link between various facets of customer satisfaction and implications on overall company profitability.
\end{abstract}

Keywords: Airlines Asia Premium Discount Customer Service Quality Profitability

\section{Introduction}

This study evaluates airlines in Asia to determine if the airlines which offer premium service perform better in the stock market than airlines which provide normal services. The study arranges two airline portfolios based on these characteristics then retrieves total return stock data for comparison to various benchmarks using the strategy of comparing long-run returns against an appropriate benchmark (Barber \& Lyon, 1997). The benchmarks include the global market and the oil market. The global market provides a basis for comparison which can be utilized when comparing alternative investments. The oil market provides a basis as one of the primary costs affecting the airline industry (Yashodha, Hamid, \& Habibullah, 2016). The study fills a research gap on airline quality and its effect on airline stock market performance in the Asia sphere using the Fama and French three-factor model (Fama et al., 1993), and utilizes benchmarks to determine the existence of long-run abnormal returns (Barber et al., 1997).

Two hypotheses are included which provide more detail as to the performance of each of the portfolio groups against the selected benchmarks. Monthly data points are included between September 2012 and October 2017. These sixty two months provide a view to airline performance for more than five of the most recent years available. A total of six cases are run, three for each portfolio, which show how the portfolios perform again the global market, the oil market, and a combination of both markets. The results confirm that the stock return performance of the portfolio of premium service airlines is superior to the portfolio of normal service airlines.

Included in the paper are discussions of customer satisfaction across industries, and their applicability in the airline industry. These topics are expanded to further focus on specific areas including service quality, loyalty, and profitability. These areas are subsequently expanded to include relevant dialog regarding hospitality; airline differentiation; passenger expectations; globalization and demographics; reliability and aircraft condition; inflight services and customer interaction; loyalty and corporate image; ticket pricing and value; firm positioning; plus the link between customer satisfaction and profitability.

This study includes research on service quality applicable to many industries (Whiteley, 1991; Kaynak, Kucukemiroglu, \& Kara, 1994; Park, Robertson, \& Wu, 2006; Lashley, 2008; Buchanan \& Clinton, 2010; Sukati, Khiang, \& Isnurhadi, 2015) and how the increased customer satisfaction leads to loyalty and customer image (Reichheld, 1990; Kaynak et al., 1994; Oliver, 1999; Park et al., 2006; Khan \& Digout, 2017). There is also research on airfares and their effect on competition (Kim \& Singal, 1993; Kaynak et al., 1994; Das \& Reisel, 
1997; Rubin \& Joy, 2005; Park et al., 2006; Gures, Arslan, \& Tun, 2014; Sukati et al., 2015; Barrows, 2018).

In addition, there are numerous research articles on airlines and how customers perceive them (Parasuraman, Zeithaml, \& Berry, 1985; Kaynak et al., 1994; Oum \& Yu, 2005; Park et al., 2006; Clemes, Gan, Kao, \& Choong, 2008; Nameghi, 2013; Ansari \& Qadri, 2014; Gures et al., 2014; Sukati et al., 2015). Lastly, there is research documenting the impacts of better service on airlines and their effects on profitability (Parasuraman et al., 1985; Porter, 1985; Reichheld, 1990; Park et al., 2006; Ansari et al., 2014; Helleloid, Nam, Schultz, \& Vitton, 2015) and how company performance can be measured explicitly by stock market returns (Yashodha et al., 2016; Barrows, 2017).

\section{Literature Review}

Building a successful business is difficult. There are many moving targets. Some which management can control, but many of which management cannot control. In the final analysis, however, building a successful business requires just one item: satisfied customers. "Customer satisfaction is a key for a company" at least those companies looking to build customer loyalty and repeat business (Sukati et al., 2015). But what exactly is customer satisfaction? Customer satisfaction can be viewed as a positive evaluation after consuming a product or service (Tse \& Wilton, 1988).

How a company treats its customers is a reflection on how hospitable a firm is. Hospitality is the formal and informal exchange between customer and company (Lashley, 2008). A satisfied customer can be defined as one that has experienced "pleasurable fulfilment" (Oliver, 1999). Looked at another way, customer satisfaction can be thought of as the comparison of expectation before and realization after of the value of a product or service (Tse et al., 1988). In other words, hospitality is meeting the needs of the customer (Lashley, 2008).

\subsection{Service Quality}

Meeting the needs of customers is a function of a firm's service quality. "Service quality can be measured in terms of the extent to which performance as perceived by the customer meets or exceeds agree level of services" (Sukati et al., 2015). A firm can provide some basic level of service, but that will not be good enough for long term success. "You can't really gain lasting competitive advantage unless you work at both product quality and service quality" (Whiteley, 1991). The grading of service quality is the "comparison of service expectation with actual performance perceptions" (Sukati et al., 2015). However, in many industries, customer service is so poor as to reduce customer expectations (Buchanan et al., 2010).

Some firms within certain industries should concentrate on "mere satisfaction" as their focus (Oliver, 1999). This may be the case until they can create better attitudes toward the customer and see the potential benefits. Where the customer and company personnel interact, attitudes of the company personnel can have a great bearing on the perceived service level from the customer viewpoint (Buchanan et al., 2010).

Successful companies are those which utilize better customer service (Whiteley, 1991). "Satisfaction remains a worthy pursuit among the consumer marketing community" (Oliver, 1999). In some quarters, there are questions about the link "between service quality and customer satisfaction" (Park et al., 2006). It seems obvious that improved service quality will benefit both the customers and the firm. Hence, "most companies assume that there is a strong relationship between customer satisfaction and consumer behavior" (Park et al., 2006).

Quality matters not only in industries in general, but especially in those industries where the offerings are similar (Buchanan et al., 2010). As further globalization occurs, many industries are facing similar issues. "In airlines as well as many other industries, everyone has essentially the same products and services", and this makes differentiation possible only through some perceived benefit, such as lower fares or improved services (Buchanan et al., 2010).

Air travel is being impacted by many factors including "globalization, environmentalism, urbanization, a more diverse and aging population, and the high technology explosion" (Oum et al., 2005). Issues such as "demographic, legal-political, socioeconomic and technological changes have led the way to transformation of the airline and the way they do business" (Kaynak et al., 1994). This has changed the game for many industries. "In the airline industry, service quality is important because delivering high quality service to passengers is essential for airlines' survival" (Park et al., 2006).

Expectations have changed and passengers want more value. "Tourists and passengers expect pleasure and memorable experience from tourism related services" (Nameghi, 2013). Customer satisfaction for air travelers can be increased if the customer better understands the quality of service offered by an airline (Park et al., 2006). For instance, the implementation of new planes and facilities should include benefits to be realized by the customer (Kaynak et al., 1994). As a result, airline competition is increasing along with the increased passenger 
expectation for better services (Ansari et al., 2014).

Marketing which is focused on the customer, using an integrated approach, generates improved customer satisfaction and improved airline industry bottom line performance (Kaynak et al., 1994). Globalization and aging demographics currently have the biggest immediate impact on air service requirements (Oum et al., 2005). These changes highlight the need for improved services. Because of this dynamic, "in this turbulent environment of global airline industry, there will always be a solid market for quality carriers" (Kaynak et al., 1994).

\subsection{Drivers of Quality}

Drivers of quality in the airline industry differ from carrier to carrier and from region to region, but can be grouped into two main areas: reliability and aircraft condition plus inflight services and customer interaction. A study based on 821 respondents whose flight type was $51 \%$ domestic in Turkey, and $49 \%$ international compiled through Turkey's four main airports identified reliability, facilities, and customer satisfaction as the primary motivating factors for the passengers (Gures et al., 2014). The study examined customer expectations and the resultant readings of satisfaction regarding the flights in question. Another study based on 376 questionnaire respondents in the US state of Pennsylvania noted that economy fares were the most preferred alternative with the primary motivating factors being reliability, satisfactory experience then price (Kaynak et al., 1994).

There is a study that confirms that reliability is paramount above the other scope of airline offerings (Parasuraman et al., 1985). Another study confirms that safety and security are seen as the most important considerations for airline passengers with on time arrivals and departures as "the least important dimension" (Clemes et al., 2008). A close relative to airline reliability is airplane condition. With regard to aircraft condition, a study conducted at the Senai Airport (Sultan Ismail International Airport) in Malaysia included 120 respondents for the Air Asia airline and found that the primary driver of "customer satisfaction is aircraft condition" (Sukati et al., 2015).

With regard to inflight services and customer interaction, there are a few studies which address these items. A study on Australia air travel with 503 respondents expressed their thoughts on airlines and had them opine that if they are "satisfied with inflight service and employee service they would be more likely to be satisfied with the airline" (Park et al., 2006). The study also measured passenger satisfaction, airline image, and ticket prices. The Australian study linked overall image to value which would make the passengers more likely to be "travelling on the airline again in the future and recommending the airline to others" (Park et al., 2006).

A study conducted at the Kuala Lumpur International Airport with 546 passengers which had the majority of respondents as leisure travelers found that traveler preferences were appreciation, courtesy, comfort, facilities, and in-flight services (Nameghi, 2013). A study on airlines in Saudi Arabia which had 400 respondents of which over $91 \%$ were Saudi citizens who flew over $57 \%$ on economy fares showed their dissatisfaction with air travel by ranking the majority of areas as unsatisfactory (Ansari et al., 2014). The results of the study were used as reasons to introduce other airlines to the Saudi market. The Saudi study found four of the six service areas related to ticketing and related services as unsatisfactory with the remaining two as "only somewhat satisfied" (Ansari et al., 2014).

\subsection{Loyalty}

With regard to attracting repeat customers, "customer satisfaction is very important in the repeat purchases" (Kaynak et al., 1994). It is obvious to most firms that there is a link between customer satisfaction and behavior (Park et al., 2006). Loyalty can be viewed as a commitment to patronize a product or service (Oliver, 1999). Businesses without loyal customers see performance reduced by roughly one-third compared to businesses with loyal customers (Reichheld, 1990). "Although loyal consumers are most typically satisfied, satisfaction does not universally translate into loyalty" (Oliver, 1999).

Loyalty can have many different definitions. For this study, loyalty is the continued use of a reputable firm and is based on the establishment of a firm's reputation (Oliver, 1999). Corporate image or reputation "is a universal concept that is relevant to all organizations around the world, regardless of their size" (Khan et al., 2017). There is research that finds "corporate image and value" are meaningful indicators of value for a firm (Park et al., 2006). This corporate image is really a byproduct of the competitive strategies used by the company. "Competitive strategy is the search for a favorable competitive position in an industry" (Porter, 1985). Therefore, corporate image or "reputation is an outcome of an organization's actions and behavior" (Khan et al., 2017).

A positive position or image is increasingly important for a company as it adds a further means to differentiation (Park et al., 2006). Attracting repeat customers is becoming a focus for airlines (Kaynak et al., 1994). This positive position or "image of a specific airline can lead to a preferred choice among their choice set when 
passengers contemplate air travel" (Park et al., 2006). As competition increases in the airline industry, there are many facets to consider. However, price is seen as the motivating factor for airline selection (Gures et al., 2014). When selecting a travel option, many people will choose the lowest price alternative (Sukati et al., 2015).

For new routes and new airlines, pricing is a way to differentiate (Kim et al., 1993). Smaller airlines and regional players may also focus on target discounts for attracting new customers (Kaynak et al., 1994). Price not only impacts the initial decision on airlines, but on overall value as well (Sukati et al., 2015). Airline passengers see the link between ticket prices and value and understand the interactions between the two as they relate to service quality (Park et al., 2006). If an airline offers a cheap fare, but offers poor service quality, customers may not return (Sukati et al., 2015). "Value (as a reflection of price) was found to have a significant positive effect on airline image" (Park et al., 2006).

\subsection{Profitability}

There are three basic strategies to position a firm in its industry: pricing, quality differentiation, and niche market focus (Porter, 1985). This may be true, but customer satisfaction cannot be overlooked. "Intensifying competition and rapid deregulation have led many service and retail businesses to seek profitable ways to differentiate themselves" (Parasuraman et al., 1985). Many decisions can be made, but the overall focus needs to be clear. "A strong customer franchise is critical to business success" (Reichheld, 1990). "Value is what buyers are willing to pay, and superior value stems from offering lower prices than competitors for equivalent benefits or providing unique benefits that more than offset a higher price" (Porter, 1985).

Buyer habits impact companies. Satisfied customers lead to improved profits (Reichheld, 1990). "Buyer power influences the prices that firms can charge, for example, as does the threat of substitution" (Porter, 1985). A firm's action with regard to pricing levels can impact the industry and its own profitability (Rubin et al., 2005). "Both industry attractiveness and competitive position can be shaped by a firm" (Porter, 1985). Hence, the quality of service is shown to increase profit levels and market share (Parasuraman et al., 1985).

There is research that confirms delivering better service in service industries can produce higher profits (Park et al., 2006). Better service means more customer retention. Businesses that attract and maintain customers "continue to generate superior results" (Reichheld, 1990). These repeat customers dramatically impact results for the better (Oliver, 1999). And thus, company profits "are influenced by repeat purchases, positive word of mouth recommendation, and customer feedback" (Ansari et al., 2014).

To increase repeat customers in the airline industry, one method would be to lower airfares. However, lowering airfares may also lower revenues and profits as well. If lowering airfares generates more passengers, then it may be beneficial. This is a key dilemma airlines face, how to generate variable business on their fixed assets without negatively impacting profitability. For new entrants, the key "is in the development of new markets and how new entrants compete in those markets against the established players" (Barrows, 2017).

It is a documented phenomenon, that "when airlines face each other in several markets they may compete less vigorously" (Kim et al., 1993). Even if airfares increase, the size of the locations had impacts on the fare increases. "Due to more intense competition in the major hubs, the airfare increases there were less than at the smaller locations" (Barrows, 2018). However, due to the fungible nature of the airline service and its low "switching costs", price wars can happen especially during slack or off-peak travel times which can result in price reductions (Das et al., 1997).

With regard to increased competition and the availability of switching airlines, these items can "intensify the downward pressure of fares" (Rubin et al., 2005). When looking at airline profitability, factors which would help the airline industry would be "an improving economy, lower oil prices..., and cost cutting efforts" (Helleloid et al., 2015). However, due to low "switching costs", price wars can occur (Das et al., 1997). Even if price wars don't occur, "having healthy competition usually results in lower fares" (Barrows, 2018).

Today, airline passengers expect more value, in addition to lower fares, they expect higher service quality and airlines will need to consider this as they implement their business plans (Park et al., 2006). In general, "customers are not happy with airlines' cost cutting or revenue building measures" (Buchanan et al., 2010). "Service quality plays an important part in customer satisfaction" in the airline industry as the airlines see long term relationships as key "in order to maximize profit" (Sukati et al., 2015).

\section{Methodology}

Measuring the stock returns is a common technique to gauge company performance. The methodology to collect and evaluate such data is the empirical-analytic approach. This type of research is focused on using objective knowledge acquired from deductive reasoning using objective data from independent third-party providers. 
Since the research question is based on share price performance, quantitative methods are used and the data enables the determination of performance with little ambiguity. There are three independent third-party providers in use to assemble the necessary data for this study: Thomson Reuters, Dartmouth College, and the US Energy Information Administration (EIA).

The data points in the stock price total return monthly percent change format for the airlines are accessed through the Eikon product from Thomson Reuters (Thomson Reuters, 2017). A comparative benchmark for the global stock market is utilized from the Center for Research in Security Prices, otherwise known as CRSP, and provided by Dartmouth College (Dartmouth, 2017). A second benchmark used is the Brent Oil market price from the EIA (EIA, 2017). The returns exclude the US one month Treasury-bill risk free rate, and the study time frame is from September 2012 through October 2017.

The objective of this study is to evaluate the stock price total returns of the companies during the sixty two month time frame. Below is the research question of this study.

\section{Research Question: In Asia, Does Airline Service Quality Matter to Investors?}

The stock price total return of the companies is the dependent variable in this analysis. The independent variables are comprised of the comparative benchmarks. The research approach is classified as causal and correlational. The intent is to establish a causal connection and quantify the relationship of the stock price total return performance of the two portfolio groups to the comparative benchmarks. To further explore this topic and focus on quantifying the research question, two hypotheses are considered.

H1: During the study time frame, the stock returns for the portfolio of Premium Service Airlines are superior relative to the benchmarks.

H2: During the study time frame, the stock returns for the portfolio of Normal Service Airlines are inferior relative to the benchmarks.

The research approach matches the monthly portfolio to other factors and is a version of the three-factor model of Fama and French (Fama et al., 1993). This method adheres with the strategy that long-run abnormal returns should be calculated as the long-run return of a sample less the long-run return of an appropriate benchmark (Barber et al., 1997). The first equation with this model formula uses three factors. The second equation is more basic and uses only two factors. In both equations, if alpha is positive, the companies outperform the market, and if alpha is negative, the companies underperform the market. The two equations are listed below.

$$
\begin{gathered}
\text { Return less RF Rate }=\alpha+\beta(\text { Global Market }-R F \text { Rate })+\beta(\text { Oil Market }-R F \text { Rate }) \\
\text { Return less RF Rate }=\alpha+\beta \text { (Global Market or Oil Market }- \text { RF Rate })
\end{gathered}
$$

This analytic approach utilizes six cases which examine the stock price total return monthly percent changes during the study time frame. For more information, please see Table 1 below.

Table 1. Analytical Cases

\begin{tabular}{ccc}
\hline Analytical Cases & Global Market & Oil Market \\
\hline 1. Premium Service Airlines & $\mathrm{X}$ & $\mathrm{X}$ \\
2. Normal Service Airlines & $\mathrm{X}$ & $\mathrm{X}$ \\
3. Premium Service Airlines & $\mathrm{X}$ & \\
4. Normal Service Airlines & $\mathrm{X}$ & \\
5. Premium Service Airlines & & $\mathrm{X}$ \\
6. Normal Service Airlines & & $\mathrm{X}$ \\
\hline
\end{tabular}

The selection of the airlines under evaluation was initially made by the data retrieval in the Thomson Reuters Eikon system by retrieving all airlines identified as publicly traded airlines from Asia. The result of this query included 27 airlines. Companies with initial trade dates more recent than September 2012 were excluded as were airlines less than $\$ 1$ billion USD in market capitalization. This reduced the 27 airlines to 18 airlines. For more information, please see Table 3 in the Appendix. With regard to categorizing airlines into various segments, one study separated airlines into three categories: international, discount, and regional (Helleloid et al., 2015). In this study, only two categories were used: premium and normal. The categorization into Premium Service Airlines and Normal Service Airlines was made based on the inclusion of the premium airlines in the article "World's 
Best Airlines for In-Flight Service 2015" from the Travel + Leisure magazine, a recognized compiler of qualitative data and opinions relating to travel and hospitality (Itzkowitz \& Lieberman, 2015). For the final list of airlines in the two categories, please see Table 4 in the Appendix.

\section{Results}

The summary results of the cases analyzed are included in Table 2 below. Cases 1 and 2 have negative alphas which show inferior performance to the benchmark combination of the global market and the oil market. Case 1 was at a statistical significance of 0.10 while case 2 was at a 0.01 statistical significance. Even though, both groups performed inferior to the combination of the two markets, the Premium Service Airlines performed better than the Normal Service Airlines when the results for each are compared against each other.

Cases 3 and 4 have negative alphas which show inferior performance to the global market. The case 3 alpha was not statistically significant while case 4 was at statistical significance of 0.01 . As in cases 1 and 2, cases 3 and 4 also performed inferior to the benchmark, but the Premium Service Airlines also performed better than the Normal Service Airlines when the results for each are compared to each other. These results are similar to returns for airplane manufacturers in another study which found "even with increased aircraft industry market power, its stock returns perform inferior to the global market" (Barrows, 2017).

Case 5 has a positive alpha which shows superior performance to the oil market while case 6 has a negative alpha which shows inferior performance to the oil market. The case 5 alpha was at a statistically significance of 0.01 while the case 6 alpha was not statistically significant. As in all of the above cases, the Premium Service Airlines performed better than the Normal Service Airlines. Based on a study including Cathay Pacific and China Airlines, "high and volatile jet fuel prices can have significant adverse effects on the stock price of these airlines" (Yashodha et al., 2016).

Table 2. Regression Statistics Table

\begin{tabular}{lccccc}
\hline \multicolumn{1}{c}{ Regressions of Analytical Cases } & Alpha (Y Intercept) & T-stat & Beta One & Beta Two & Adj. $\mathrm{R}^{2}$ \\
\cline { 2 - 6 } & $* *=10 \%, * *=5 \%, * * *=1 \%$ denote significance levels \\
\hline 1. Premium Service Airlines: Global \& Oil Markets & $(0.04) *$ & $(1.70)$ & $0.59 * * *$ & $(0.67) * * *$ & 0.90 \\
2. Normal Service Airlines: Global \& Oil Markets & $(0.26) * * *$ & $(3.40)$ & $0.87 * * *$ & $(1.08) * * *$ & 0.72 \\
3. Premium Service Airlines: Global Market & $(0.06)$ & $(1.17)$ & $1.19 * * *$ & NA & 0.64 \\
4. Normal Service Airlines: Global Market & $(0.28) * * *$ & $(2.76)$ & $1.84 * * *$ & NA & 0.51 \\
5. Premium Service Airlines: Oil Market & $0.10 * * *$ & 4.20 & $(0.93) * * *$ & NA & 0.81 \\
6. Normal Service Airlines: Oil Market & $(0.04)$ & $(0.66)$ & $(1.46) * * *$ & NA & 0.66 \\
\hline
\end{tabular}

The Adjusted R Squared readings in all cases are higher for the Premium Service Airlines as compared to the Normal Service Airlines. The readings for the Premium Service Airlines group are between 22\% and 25\% higher than the Normal Service Airlines group. This confirms that the premium group is more correlated to the benchmarks than the normal group. That being said, the Adjusted R Squared readings are at a moderate level in cases 3 and 4, but are at higher readings for cases 1,2,5, and 6. This shows that the two airline groups are more correlated to the oil market than the global market since the oil market was not included in cases 3 and 4 . The study of Cathay Pacific and China Airlines establish that there is a relationship between the airline stock price and the price of fuel (Yashodha et al., 2016). The higher Adjusted R Squared readings in cases 1, 2, 5, and 6, as compared to cases 3 and 4 confirm this relationship. Of the factors impacting the airline industry, the primary factor is the fuel price (Yashodha et al., 2016).

\section{Discussion}

In all six comparative cases, the three cases for the Premium Service Airlines performed superior to the Normal Service Airlines even though not all case results were at statistically significant levels. On the subject of hypothesis testing, using the regression techniques stipulated in the Methodology section, only three out of the six cases have alphas that are at a statistically significant level of 0.01 , with another case with an alpha at the 0.10 level, and two cases without statistically significant alphas.

With regard to the first of the hypotheses considered, H1: During the study time frame, the stock returns for the portfolio of Premium Service Airlines are superior relative to the benchmarks, the results are somewhat mixed. Cases 1 and 3 have inferior alphas, but at a 0.10 significance level in case 1, and not at a statistically significant 
level in case 3. However, in case 5, the Premium Service Airlines performed superior relative to the benchmarks, and at a significant level of 0.01 . Hence, these results confirm the $\mathrm{H} 1$ null hypothesis.

With regard to the second of the hypotheses considered, H2: During the study time frame, the stock returns for the portfolio of Normal Service Airlines are inferior relative to the benchmarks, the results are more certain. Cases 2, 4, and 6, all performed inferior to the benchmarks with cases 2 and 4 at a significant level of 0.01 and case 6 not at a statistically significant level. These results confirm the $\mathrm{H} 2$ null hypothesis.

The research question for this study is: In Asia, Does Airline Service Quality Matter to Investors? Based on the research methods in this study and the significance of the resultant measurements, a confirmation of the hypothesis is warranted. The Premium Service Airlines outperform the Normal Service Airlines in Asia. Investors who invested in a portfolio of the nine Premium Service Airlines included in this study would have higher returns than investors who invested in the Normal Service Airlines.

These results confirm other studies which document the value of improved service quality to a firm (Whiteley, 1991; Kaynak et al., 1994; Park et al., 2006; Buchanan et al., 2010; Sukati et al., 2015). With regard to reduced airfares, head to head competition does not always reduce airfares (Kim et al., 1993; Barrows, 2018), but there are certainly studies which document reducing airfares due to competition (Das et al., 1997; Rubin et al., 2005; Barrows, 2018). Price discounts on airfares are an initial draw for airline passengers (Kaynak et al., 1994; Park et al., 2006; Gures et al., 2014; Sukati et al., 2015). This is especially true for discount airlines. Cheap airfares may attract customers, but may not keep them.

With regard to airline quality, there are studies which document the need for increased airline reliability, safety, or airplane condition (Parasuraman et al., 1985; Kaynak et al., 1994; Oum et al., 2005; Clemes et al., 2008; Gures et al., 2014; Sukati et al., 2015). There are also studies which document the need for inflight services, courtesy, and customer satisfaction (Kaynak et al., 1994; Park et al., 2006; Nameghi, 2013; Ansari et al., 2014; Gures et al., 2014; Sukati et al., 2015).

In addition, increasing customer satisfaction leads to customer loyalty and improved corporate image (Reichheld, 1990; Kaynak et al., 1994; Oliver, 1999; Park et al., 2006; Khan et al., 2017). These quality differentiations can have bigger impacts (Parasuraman et al., 1985; Porter, 1985; Reichheld, 1990). This is especially true as satisfied customers drive bigger profits to airlines which provide a higher level of service (Parasuraman et al., 1985; Porter, 1985; Reichheld, 1990; Park et al., 2006; Ansari et al., 2014) and the profitability of the business as measured by the returns in the stock market (Yashodha et al., 2016; Barrows, 2017).

\section{Conclusions}

The purpose of this study is to discuss topics related service quality, loyalty, and profitability, in industries in general, and more specifically how these topics apply to the airline industry. The airlines in Asia were selected because there are numerous studies which document airfares and competition, in the US and the EU, but not in Asia. Some of the regulatory expectations in the US and the EU do not apply to Asia since there is not an overarching body which governs the industry there. There is less regulatory structure, and perhaps more freedom, so airlines operating in Asia might be expected to have increased flexibility.

There are many premium airlines operating in the Asia sphere. Service quality is a hot topic with some airlines still preferring to compete more on price while others offer improved services. The nine airlines selected in the Premium Services Airlines group were identified as providing superior services, without a reference to airfares. Increasing the quality of services and customer satisfaction can have real impacts on profitability of not only the airlines in this study, but for business in general.

Differentiation is of value to a company, whether it be through pricing or through improved services. The results of this study show that there is a measurable value for the companies that provide the better service, in this case, improved stock results during the study time frame. The fact that the Premium Service Airlines perform better than the Normal Service Airlines in Asia should be a comfort to those who think that airline service quality still matters to investors.

\section{References}

Ansari, Z. A., \& Qadri, F. A. (2014). An Analysis of the Customer Satisfaction from the Service Quality of General Services of Saudi Airlines. International Review of Management and Business Research, 3(3), 1564. Retrieved December 1, 2017, from https://www.questia.com/library/journal/1P3-3475528381/an-analysisof-the-customer-satisfaction-from-the

Barber, B., \& Lyon, J. (1997). Detecting long-run abnormal stock returns: The empirical power and specification 
of test statistics. Journal of Financial Economics, 43(3), 341-372. https://doi.org/10.1016/S0304-405X(96) 00890-2

Barrows, S. D. (2017). With Increased Market Power, Do Aircraft Industry Stock Returns Beat Global Market? International Review of Management and Marketing, 7(5), 63-69. Retrieved December 8, 2017, from http://www.econjournals.com/index.php/irmm/article/view/5695/pdf

Barrows, S. D. (2018). After the US airline mergers, did domestic airfares increase? International Review of Management and Marketing, 8(1), 1-8. Retrieved January 5, 2018, from http://www.econjournals.com/index.php/irmm/article/view/5739/pdf

Buchanan, F. R., \& Clinton, M. S. (2010). Customer Service in the United States. Journal of Behavioral and Applied Management, 11(3), 279. Retrieved December 9, 2017, from https://www.questia.com/read/1P32053919761/customer-service-in-the-united-states

Clemes, M. D., Gan, C., Kao, T. H., \& Choong, M. (2008). An empirical analysis of customer satisfaction in international air travel. Innovative Marketing, 4(2), 50-62. Retrieved December 10, 2017, from https://www.econbiz.de/Record/an-empirical-analysis-of-customer-satisfaction-in-international-air-travel-cl emes-michael/10003801278

Das, T., \& Reisel, W. (1997). Strategic marketing options in the U. S. airline industry. International Journal of Commerce and Management, 7(2), 84-98. https://doi.org/10.1108/eb047350

Fama, E., \& French, K. (1993). Common risk factors in returns on stocks and bonds. Journal of Financial Economics, 33(1), 3-56. https://doi.org/10.1016/0304-405X(93)90023-5

Gures, N., Arslan, S., \& Tun, S. Y. (2014). Customer Expectation, Satisfaction and Loyalty Relationship in Turkish Airline Industry. International Journal of Marketing Studies, 6(1). https://dx.doi.org/10.5539/ijms.v6n1p66

Helleloid, D., Nam, S., Schultz, P., \& Vitton, J. (2015). The U.S. Airline Industry in 2015. Journal of the International Academy for Case Studies, 21(5), July, 113+. Retrieved December 12, 2017, from https://www.questia.com/read/1G1-499492471/the-u-s-airline-industry-in-2015

Itzkowitz, L., \& Lieberman, M. (2015). World's Best Airlines for In-Flight Service 2015. Travel + Leisure. Retrieved from http://www.travelandleisure.com/slideshows/worlds-best-airlines-in-flight-service\#1

Kaynak, E., Kucukemiroglu, O., \& Kara, A. (1994). Consumers' Perceptions of Airlines: A Correspondence Analysis Approach in a Global Airline Industry. Management International Review, 34(3), 235. Retrieved from https://www.questia.com/read/1G1-16374090/consumers-perceptions-of-airlines-a-correspondence

Khan, S., \& Digout, J. (2017). The Corporate Reputation Reporting Framework (CRRF). Corporate Reputation Review, 1-15. https://doi.org/10.1057/s41299-017-0041-4

Kim, E., \& Singal, V. (1993). Mergers and Market Power: Evidence from the Airline Industry. The American Economic Review, 83(3), 549-569. Retrieved November 15, 2017, from http://www.jstor.org/stable/2117533?seq=1\#page_scan_tab_contents

Lashley, C. (2008). Studying Hospitality: Insights from Social Sciences. Scandinavian Journal of Hospitality and Tourism, 8(1), 69-84. https://dx.doi.org/10.1080/15022250701880745

Nameghi, E. N. M. (2013). The Relationship between Private Domain and Commercial Domain of Hospitality in Airlines: Employing Partial Least Square Technique. International Journal of Marketing Studies, 5(2), 102. https://doi.org/10.5539/ijms.v5n2p102

Oliver, R. L. (1999). Whence consumer loyalty. Journal of Marketing, 63(Special Issue), 33-44. https://doi.org/10.5539/ijms.v5n2p102

Oum, T. H., \& Yu, C., (2005). Transportation Policy and Management: Introduction to the Special Issue. Canadian J. of Administrative Sciences, 22(1), 1-2. https://doi.org/10.1111/j.1936-4490.2005.tb00356.x

Park, J. W., Robertson, R., \& Wu, C. L. (2006). The Effects of Individual Dimensions of Airline Service Quality: Findings from Australian Domestic Air Passengers. Journal of Hospitality and Tourism Management, 13(2), 161. https://doi.org/10.1375/jhtm.13.2.161

Parasuraman, A., Zeithaml, V. A., \& Berry, L. L. (1985). SERVQUAL: A Multiple - Item Scale for measuring consumer perceptions of service quality. J. of Retailing, 64, 12-40. https://doi.org/10.4135/9781446263426

Porter, E. M. (1985). Competitive Advantage: Creating and Sustaining Superior Performance. New York, NY: 
The Free Press.

Reichheld, F. F. (1990). The loyalty effect. Boston: Harvard Business School Press.

Rubin, R., \& Joy, J. (2005). Where Are the Airlines Headed? Implications of Airline Industry Structure and Change for Consumers. The Journal of Consumer Affairs, 39(1), 215-228. https://doi.org/10.1111/j.17456606.2005.00010.x

Sukati, I., Khiang, T. B., \& Isnurhadi. (2015). Customer Satisfaction Level Provided by Air Asia. Asian Social Science, 11(13), 16. https://doi.org/10.5539/ass.v11n13p16

Tse, D. K., \& Wilton, P. C. (1988). Models of consumer satisfaction formation: An extension. Journal of Marketing Research, 25, 204-212. https://doi.org/10.2307/3172652

Whiteley, R. (1991). The customer-driven company. Reading, MA: Addison-Wesley.

Yashodha, Y., Hamid, B. A., \& Habibullah, M. S. (2016). Financial Risk Exposures of the Airlines Industry: Evidence from Cathay Pacific Airways and China Airlines. International Journal of Business and Society, 17(2), 221. Retrieved December 2, 2017, from https://www.questia.com/library/journal/1P3-4171373691/ financial-risk-exposures-of-the-airlines-industry

\section{Appendix}

Table 3. Airline Initial Retrievals

\begin{tabular}{|c|c|c|c|c|c|}
\hline $\begin{array}{c}\text { Airlines from Thomson Reuters Asia } \\
\text { Airlines retrieval }\end{array}$ & $\begin{array}{l}\text { Trading } \\
\text { Symbol }\end{array}$ & $\begin{array}{l}\text { Market } \\
\text { cap. }\end{array}$ & $\begin{array}{l}\text { Initial trade } \\
\text { in retrieval }\end{array}$ & $\begin{array}{l}\text { Reject } \\
\text { Reason }\end{array}$ & Category \\
\hline Air China Ltd & 0753.HK & $22.05 \mathrm{~B}$ & Jan-09 & & Normal \\
\hline China Southern Airlines Co Ltd & 1055.HK & $14.76 \mathrm{~B}$ & Jan-09 & & Normal \\
\hline ANA Holdings Inc & 9202.T & 14.44B & Jan-09 & & Premium \\
\hline China Eastern Airlines Corp Ltd & 0670.HK & 13.84B & Jan-09 & & Normal \\
\hline Japan Airlines Co Ltd & 9201.T & $13.38 \mathrm{~B}$ & Sep-12 & & Premium \\
\hline Singapore Airlines Ltd & SIAL.SI & $9.36 \mathrm{~B}$ & Jan-09 & & Premium \\
\hline Qantas Airways Ltd & QAN.AX & $7.07 \mathrm{~B}$ & Jan-09 & & Premium \\
\hline InterGlobe Aviation Ltd & INGL.NS & $6.78 \mathrm{~B}$ & Nov-15 & Trade date & \\
\hline Cathay Pacific Airways Ltd & 0293.HK & $5.97 \mathrm{~B}$ & Jan-09 & & Premium \\
\hline Korean Air Lines Co Ltd & 003490.KS & $2.89 \mathrm{~B}$ & Jan-09 & & Premium \\
\hline Vietjet Aviation JSC & VJC.HM & $2.66 \mathrm{~B}$ & Mar-17 & Trade date & \\
\hline AirAsia Bhd & AIRA.KL & $2.65 \mathrm{~B}$ & Jan-09 & & Normal \\
\hline Air New Zealand Ltd & AIR.NZ & $2.49 \mathrm{~B}$ & Jan-09 & & Premium \\
\hline China Airlines Ltd & 2610.TW & $2.18 \mathrm{~B}$ & Jan-09 & & Normal \\
\hline Eva Airways Corp & 2618.TW & $2.15 \mathrm{~B}$ & Jan-09 & & Normal \\
\hline Virgin Australia Holdings Ltd & VAH.AX & $1.69 \mathrm{~B}$ & Jan-09 & & Premium \\
\hline Spicejet Ltd & SPJT.BO & $1.30 \mathrm{~B}$ & Jan-09 & & Normal \\
\hline Cebu Air Inc & CEB.PS & $1.20 \mathrm{~B}$ & Jan-09 & & Normal \\
\hline Jet Airways (India) Ltd & JET.NS & $1.20 \mathrm{~B}$ & Jan-09 & & Normal \\
\hline Thai Airways International PCL & THAI.BK & $1.14 \mathrm{~B}$ & Jan-09 & & Premium \\
\hline Bangkok Airways PCL & BA.BK & $1.11 \mathrm{~B}$ & Nov-14 & Trade date & \\
\hline Hanjinkal & 180640.KS & $1.01 \mathrm{~B}$ & Sep-13 & Trade date & \\
\hline Asia Aviation PCL & AAV.BK & $0.93 \mathrm{~B}$ & Jan-09 & Market cap & \\
\hline Asiana Airlines Inc & 020560.KS & $0.88 \mathrm{~B}$ & Jan-09 & Market cap & \\
\hline Jeju Air Co Ltd & 089590.KS & $0.85 \mathrm{~B}$ & Nov-15 & Market cap & \\
\hline Garuda Indonesia (Persero) Tbk PT & GIAA.JK & $0.58 \mathrm{~B}$ & Jan-09 & Market cap & \\
\hline AirAsia X Bhd & AIRX.KL & $0.34 \mathrm{~B}$ & Jul-13 & Market cap & \\
\hline
\end{tabular}


Table 4. Airline Groupings

\begin{tabular}{ll}
\hline Premium Service Airlines (by market cap) & Normal Service Airlines (by market cap) \\
\hline ANA Holdings Inc & Air China Ltd \\
Japan Airlines Co Ltd & China Southern Airlines Co Ltd \\
Singapore Airlines Ltd & China Eastern Airlines Corp Ltd \\
Qantas Airways Ltd & AirAsia Bhd \\
Cathay Pacific Airways Ltd & China Airlines Ltd \\
Korean Air Lines Co Ltd & Eva Airways Corp \\
Air New Zealand Ltd & Spicejet Ltd \\
Virgin Australia Holdings Ltd & Cebu Air Inc \\
Thai Airways International PCL & Jet Airways (India) Ltd \\
\hline
\end{tabular}

\section{Copyrights}

Copyright for this article is retained by the author(s), with first publication rights granted to the journal.

This is an open-access article distributed under the terms and conditions of the Creative Commons Attribution license (http://creativecommons.org/licenses/by/4.0/). 